\title{
A Study on the Modern Kitchen Users' Satisfaction about the After Sales Service Performance of Modern Kitchen and its Appliances in Coimbatore District
}

\author{
D. Parimala Devi* \\ Assistant Professor, Department of Business Administration with CA, Vellalar College for Women, Erode, Tamil Nadu, \\ India; bamasaran08@gmail.com
}

\begin{abstract}
Cooking had given an infinite space area in earlier days. As time advanced, households built a separate building for the kitchen. Technological advances during industrialization brought major changes to the kitchen. The modern, independent stylish woman's relationship with the kitchen is very unique today. The expectations and preferences of women towards a modern kitchen are not only a place for storing, cooking, preparing food and doing related tasks but also a storehouse of luxury and beauty where woman expects to use it for dining, entertaining, exhibiting etc. So, the views and preferences of women towards kitchen changes by the choices and availability of after sales services too. The more and more electric and electronic kitchen appliances with elaborate functions made woman to think the kitchen in a different way. In this aspect, the present study is an attempt to know the satisfaction of modern kitchen users about after sales service offered for the modern kitchen tools.
\end{abstract}

Keywords: Modern Kitchen Tools, Satisfaction and Technology

\section{Introduction}

In recent years, expectations of the homemakers towards kitchen have changed from traditional to modern and modern to ultra-modern. The expectations and preferences in the kitchen differ according to the socio-economic features. In few households, even the kitchen is maintained by the paid servant maids. The women in the house are dominating and make the maids to keep the kitchen in such a way by utilizing the improved and technologically enabled modern kitchen and its appliances. Modern Kitchen retail sector gets various opportunities to grow in the Indian market. The improved technology has brought a vast change in the outlay of kitchen. In today's tech savvy era, modern kitchen is the favourite aspect of women. The maintenance of modern kitchen becomes very essential to proceed with comfortable household work. The after sales service plays a vital role in maintaining the modern kitchen. Hence, the present study is an attempt to know the level of satisfaction of the modern kitchen users about the after sales service provided for modern kitchen and its appliances in Coimbatore District.

\section{Statement of the Problem}

Women are facing with drudgery during food preparation. The kitchen related problems can be solved by designing kitchens that are satisfactory to the users which lead to the development of Modern Kitchen. Modern Kitchen has shown tremendous positive effect on human wellbeing that leads to classy modern kitchen. The kitchen developers should offer the most advanced, smart, intuitive space-saving and time and energy saving technology enabled modern kitchens to increase the comfort and accessibility along with best after sales services. Thus, an attempt has been made by the researcher to study the after sales services provided by marketers. 


\section{Objectives of the Study}

- To know the socio-economic characteristics of the modern kitchen users and

- To analyse the users' level of satisfaction towards the after sales services offered for modern kitchen and its appliances.

\section{Research Methodology}

The present study was extensive and used both primary and secondary data. Stratified Random Sampling Technique was applied to select the sample respondents from the Coimbatore District. The size of sample was 500 respondents. For collecting primary data, field survey technique was employed in Coimbatore District. A well framed questionnaire was used to collect the primary data. The collected data were analysed by employing Simple Percentage Analysis and Structural Equation Model.

\section{Analysis and Discussion}

\subsection{Socio-Economic Characteristics - Percentage Analysis}

The socio-economic characteristics of the respondents is analysed by using Simple Percentage Analysis and the results are shown in Table 1.

Table 1. Socio-Economic Characteristics of Modern Kitchen Users

\begin{tabular}{|c|c|c|c|c|}
\hline S.No. & $\begin{array}{l}\text { Socio-Economic } \\
\text { Characteristics }\end{array}$ & Options & No. of Respondents & Percentage (\%) \\
\hline \multirow[t]{5}{*}{1.} & \multirow[t]{5}{*}{ Age } & Upto 25 Years & 48 & 9.6 \\
\hline & & 26-40 Years & 224 & 44.8 \\
\hline & & 41-50 Years & 136 & 27.2 \\
\hline & & Above 50 Years & 92 & 18.4 \\
\hline & & Total & 500 & 100.0 \\
\hline \multirow[t]{5}{*}{2.} & \multirow[t]{5}{*}{ Educational Qualification } & School Level & 73 & 14.6 \\
\hline & & College Level & 219 & 43.8 \\
\hline & & Professional & 160 & 32.0 \\
\hline & & No Formal Education & 48 & 9.6 \\
\hline & & Total & 500 & 100.0 \\
\hline \multirow[t]{6}{*}{3.} & \multirow[t]{6}{*}{ Occupational Status } & Businesswoman & 66 & 13.2 \\
\hline & & Govt. Employee & 156 & 31.2 \\
\hline & & Private Employee & 62 & 12.4 \\
\hline & & House Wife & 185 & 37.0 \\
\hline & & Other & 31 & 6.2 \\
\hline & & Total & 500 & 100.0 \\
\hline \multirow[t]{5}{*}{4.} & \multirow[t]{5}{*}{ Family Monthly Income } & Upto Rs.50,000 & 82 & 16.4 \\
\hline & & Rs. $50,001-1,00,000$ & 115 & 23.0 \\
\hline & & Rs. $1,00,001-2,00,000$ & 227 & 45.4 \\
\hline & & Above Rs.2,00,000 & 76 & 15.2 \\
\hline & & Total & 500 & 100.0 \\
\hline \multirow[t]{3}{*}{5.} & \multirow[t]{3}{*}{ Marital Status } & Married & 304 & 60.8 \\
\hline & & Unmarried & 196 & 39.2 \\
\hline & & Total & 500 & 100.0 \\
\hline \multirow[t]{4}{*}{6.} & \multirow[t]{4}{*}{ Family Size } & Up to 3 Members & 94 & 18.8 \\
\hline & & 4 to 6 Members & 293 & 58.6 \\
\hline & & Above 6 Members & 113 & 22.6 \\
\hline & & Total & 500 & 100.0 \\
\hline
\end{tabular}




\begin{tabular}{|c|c|c|c|c|}
\hline S.No. & $\begin{array}{l}\text { Socio-Economic } \\
\text { Characteristics }\end{array}$ & Options & No. of Respondents & Percentage (\%) \\
\hline \multirow[t]{4}{*}{7.} & \multirow[t]{4}{*}{ Living Area } & Urban & 245 & 49.0 \\
\hline & & Semi-Urban & 205 & 41.0 \\
\hline & & Rural & 50 & 10.0 \\
\hline & & Total & 500 & 100.0 \\
\hline \multirow[t]{3}{*}{8.} & \multirow[t]{3}{*}{ Dwelling Place } & Own House & 272 & 54.4 \\
\hline & & Rented House & 228 & 45.6 \\
\hline & & Total & 500 & 100.0 \\
\hline \multirow[t]{6}{*}{9.} & \multirow[t]{6}{*}{ Type of Kitchen Design } & Single-Line Kitchen & 100 & 20.0 \\
\hline & & Two-Line Kitchen & 100 & 20.0 \\
\hline & & L-Shaped Kitchen & 100 & 20.0 \\
\hline & & U-Shaped Kitchen & 100 & 20.0 \\
\hline & & Island Kitchen & 100 & 20.0 \\
\hline & & Total & 500 & 100.0 \\
\hline
\end{tabular}

\section{Source: Computed}

It is found from Table 1 that the majority of $44.8 \%$ of the respondents belong to the age group of 26 - 40 years, $43.8 \%$ of the respondents are educated upto college level, $37 \%$ of the respondents are housewives, $45.4 \%$ of the respondents earn a monthly family income of Rs.1,00,001 to 2,00,000, $60.8 \%$ of the respondents are married, $58.6 \%$ of the respondents are having 4 to 6 members in their family, $49 \%$ of the respondents live in urban area and $54.4 \%$ of the respondents dwell in their own house. It is also found that the same percentage $(20 \%)$ of the respondents are using single- line kitchen, two-line kitchen, L-shaped kitchen, U-shaped kitchen and island type of kitchen.

\subsection{Level of Satisfaction towards After Sales Service}

The level of satisfaction of the respondents towards the after sales service offered for modern kitchen is analysed and the results are shown in Table 2.

Table 2. Level of Satisfaction Towards After Sales Service

\begin{tabular}{|c|l|r|r|r|r|r|}
\hline S.No. & \multicolumn{1}{|c|}{ Factors } & $\begin{array}{c}\text { Highly } \\
\text { Satisfied }\end{array}$ & Satisfied & Neutral & Dissatisfied & $\begin{array}{c}\text { Highly } \\
\text { Dissatisfied }\end{array}$ \\
\hline 1 & Warranty and guarantee for modern & $\begin{array}{r}172 \\
(34.4)\end{array}$ & $\begin{array}{r}140 \\
(28.0)\end{array}$ & $\begin{array}{r}108 \\
(21.6)\end{array}$ & $\begin{array}{r}54 \\
(10.8)\end{array}$ & $\begin{array}{r}26 \\
(5.2)\end{array}$ \\
\hline 2 & kitchen tools & $\begin{array}{r}125 \\
(25.0)\end{array}$ & $\begin{array}{r}193 \\
\text { Usage of modern kitchen }\end{array}$ & $\begin{array}{r}99 \\
(19.6)\end{array}$ & $\begin{array}{r}52 \\
(10.4)\end{array}$ & $\begin{array}{r}31 \\
(6.2)\end{array}$ \\
\hline 3 & Reols & 62 & 175 & 83 & 137 & 43 \\
& Reminding of free service for regular \\
maintenance of electronically & $(12.4)$ & $(35.0)$ & $(16.6)$ & $(27.4)$ & $(8.6)$ \\
\hline 4 & advanced kitchen tools & 167 & 209 & 66 & 30 & 28 \\
& Quick and regular availability of & $(33.4)$ & $(41.8)$ & $(13.2)$ & $(6.0)$ & $(5.6)$ \\
\hline 5 & Time taken for grievance redressal & 150 & 287 & 31 & 15 & 17 \\
& & $(30.0)$ & $(57.4)$ & $(6.2)$ & $(3.0)$ & $(3.4)$ \\
\hline 6 & Smartness of servicemen in attending & 103 & 230 & 91 & 29 & 47 \\
& the problem & $(20.6)$ & $(46.0)$ & $(18.2)$ & $(5.8)$ & $(9.4)$ \\
\hline 7 & Charges levied for maintenance & 136 & 142 & 159 & 30 & 33 \\
& & $(27.2)$ & $(28.4)$ & $(31.8)$ & $(6.0)$ & $(6.6)$ \\
\hline
\end{tabular}




\begin{tabular}{|c|l|c|c|r|r|r|}
\hline S.No. & \multicolumn{1}{|c|}{ Factors } & $\begin{array}{c}\text { Highly } \\
\text { Satisfied }\end{array}$ & Satisfied & Neutral & Dissatisfied & $\begin{array}{c}\text { Highly } \\
\text { Dissatisfied }\end{array}$ \\
\hline 8 & $\begin{array}{l}\text { Electricity consumption in the usage } \\
\text { of modern kitchen }\end{array}$ & $\begin{array}{r}112 \\
(22.4)\end{array}$ & $\begin{array}{r}163 \\
(32.6)\end{array}$ & $\begin{array}{r}84 \\
(16.8)\end{array}$ & $\begin{array}{r}76 \\
(15.2)\end{array}$ \\
\hline 9 & $\begin{array}{l}\text { Tips and demo for the newly } \\
\text { introduced technically advanced } \\
\text { kitchen tools }\end{array}$ & $\begin{array}{r}106 \\
(21.2)\end{array}$ & $\begin{array}{r}88 \\
(17.6)\end{array}$ & $\begin{array}{r}153 \\
(30.6)\end{array}$ & $\begin{array}{r}110 \\
(22.0)\end{array}$ \\
\hline
\end{tabular}

Figures in parentheses represent percentage.

It is revealed from Table 2 that the majority of $34.4 \%$ of the respondents are highly satisfied towards 'Warranty and guarantee for modern kitchen tools', $38.6 \%$ of the respondents are satisfied towards 'Usage of modern kitchen tools', 35\% towards 'Reminding of free service for regular maintenance of electronically advanced kitchen tools', $41.8 \%$ towards 'Quick and regular availability of service personnel in case of repair', $57.4 \%$ towards 'Time taken for grievance redressal', $46 \%$ towards 'Smartness of servicemen in attending the problem' and $32.6 \%$ of the respondents towards 'Electricity consumption in the usage of modern kitchen', $31.8 \%$ and $30.6 \%$ of the respondents are neutrally satisfied towards 'Charges levied for maintenance' and 'Tips and demo for the newly introduced technically advanced kitchen tools' respectively.

\subsection{Relationship between Various After Sales Service Dimensions Influencing Level of Satisfaction}

In the present study, an attempt was made to find the relationship between various dimensions of the after sales service performance among the modern kitchen users in Coimbatore District. For this purpose, after sales service performance has been measured in nine dimensions by framing null hypotheses.

$\mathrm{H}_{0(1-9)}$ : There is no positive association between the selected nine exogenous variables and endogenous variable namely 'After Sales Service.'

The structural equation model was conducted to assess the construct validity by using the maximum likelihood method. The confirmatory test result showed good fit as shown in Table 3.

Table 3. Model Fit Summary

\begin{tabular}{|c|l|c|c|c|}
\hline S.No. & Test Factor & Value & Criteria $^{1,2,3}$ & Result \\
\hline 1 & Chi-Square & 121.25 & $\mathrm{p}>0.05$ & $1 \%$ level \\
\hline 2 & $\begin{array}{l}\text { Chi-Square / df } \\
(27)\end{array}$ & 4.491 & $2.0-5.0$ & Good Fit \\
\hline 3 & GFI & 0.989 & $>0.95$ & Good Fit \\
\hline
\end{tabular}

\begin{tabular}{|c|l|c|c|c|}
\hline S.No. & Test Factor & Value & Criteria $^{1,2,3}$ & Result \\
\hline 4 & AGFI & 0.977 & $>0.95$ & Good Fit \\
\hline 5 & $\begin{array}{l}\text { CFI } \\
\text { (Comparative } \\
\text { fit index) }\end{array}$ & 0.976 & $>0.95$ & Good Fit \\
\hline 6 & $\begin{array}{l}\text { NFI (Normal fit } \\
\text { index) }\end{array}$ & 0.957 & $>0.95$ & Good Fit \\
\hline 7 & $\begin{array}{l}\text { TLI (Tucker- } \\
\text { Lewis index) }\end{array}$ & 0.951 & $>0.95$ & Good Fit \\
\hline 8 & $\begin{array}{l}\text { RMSEA } \\
\text { (Root mean } \\
\text { square error of } \\
\text { approximation) }\end{array}$ & 0.042 & $<0.07$ & Good Fit \\
\hline
\end{tabular}

\section{Source: Computed}

It is found from Table 3 that the estimated value for the model is 4.491 which satisfy the required condition. Similarly, the estimated value of Root Mean Square Error of Approximation (RMSEA) is 0.042 which is less than 0.07 and it highly validates the result. Similarly, model fit indices (GFI-0.989, AGFI-0.977, CFI-0.976, NFI-0.957 and TLI-0.951) for the model indicates that the model fits well. The figure 1 gives the resulted hypotheses model.

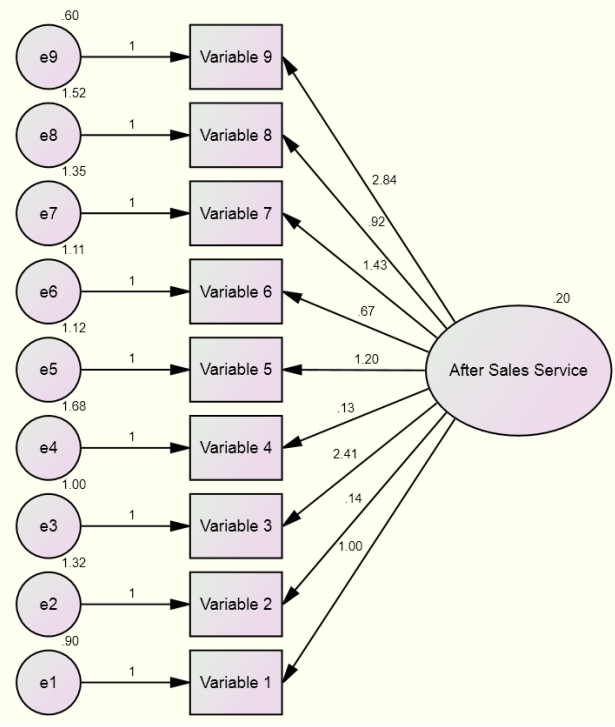

Figure 1: Resulted hypotheses model - After sales service 
The regression weights of the results are discussed in Table 4 .

Table 4. Regression Weights

\begin{tabular}{|c|l|l|c|c|c|c|}
\hline Endogenous Variable & & Exogenous Variable & Estimate & S.E. & C.R. & 'p' Value \\
\hline & $\rightarrow$ & Variable 1 & 1.000 & & & \\
\cline { 2 - 7 } & $\rightarrow$ & Variable 2 & 0.144 & 0.128 & 1.123 & $0.261^{\text {NS }}$ \\
\cline { 2 - 7 } & $\rightarrow$ & Variable 3 & 2.407 & 0.282 & 8.541 & $0.000^{* *}$ \\
\cline { 2 - 7 } & $\rightarrow$ & Variable 4 & 0.134 & 0.144 & 0.933 & $0.351^{\text {NS }}$ \\
\cline { 2 - 8 } & $\rightarrow$ & Variable 5 & 1.197 & 0.173 & 6.900 & $0.000^{* *}$ \\
\cline { 2 - 8 } & $\rightarrow$ & Variable 6 & 0.673 & 0.137 & 4.900 & $0.000^{* *}$ \\
\cline { 2 - 8 } & $\rightarrow$ & Variable 7 & 1.427 & 0.200 & 7.147 & $0.000^{* *}$ \\
\cline { 2 - 8 } & $\rightarrow$ & Variable 8 & 0.921 & 0.168 & 5.469 & $0.000^{* *}$ \\
\cline { 2 - 7 } & $\rightarrow$ & Variable 9 & 2.840 & 0.327 & 8.675 & $0.000^{* *}$ \\
\hline
\end{tabular}

Note $:^{* *}$ - Significant at $1 \%$ level

It is noted from the analysis that all the variables are having positive association with the endogenous variable 'After Sales Service'. The Variable 2 (Usage of modern kitchen tools) and Variable 4 (Quick and regular availability of service personnel in case of repair) are not having significant association with 'After Sales Service. The Variable 3 (Reminding of free service for regular maintenance of electronically advanced kitchen tools), Variable 5 (Time taken for grievance redressal), Variable 6 (Smartness of servicemen in attending the problem), Variable 7 (Charges levied for maintenance), Variable 8 (Electricity consumption in the usage of modern kitchen) and Variable 9 (Tips and demo for the newly introduced technically advanced kitchen tools) are having significant positive association with 'After Sales Services'.

\section{Suggestions}

- The distributors of modern kitchen appliances should provide timely service through follow up and clear demo in using the modern kitchen tools to the consumers after their first purchase.

- The consumers have to purchase the modern kitchen appliances based on the quality and standard as it involves consumption of electricity.

\section{Conclusion}

It is inferred from the study that all the variables considered are having positive association with 'After Sales Service' except 'Usage of modern kitchen tools' and 'Quick and regular availability of service personnel in case of repair'. In order to achieve higher comfort level in the kitchen, designers have to manufacture the products to suit the tastes and preferences of all categories of people. Designers can incorporate the much desired considerations into the design of kitchens along with timely after sales services. By improving the services, the modern kitchen will become the style of every kitchen. The satisfaction of women users by the modern kitchen designers will thus increase the reputation and sales of the modern kitchen appliances.

\section{References}

1. Schumacker, Lomax. A Beginner's Guide to Structural Equation Modeling. $2^{\text {nd }}$ ed. New Jersey: Lawrence Erlbaum Associates; 2004

2. Hu LT, Bentler PM. Cutoff criteria for fit indexes in covariance structural analysis: Conventional criteria versus new alternatives, Structural Equation Model. 1999; 6:1-55. https:// doi.org/10.1080/10705519909540118

3. Hair JF. Jr, Anderson RE, Tatham RL, Black WC. Multivariate data analysis. $5^{\text {th }}$ ed., Upper Saddle River, NJ: Prentice-Hall International; 1998. 